\title{
Mutual Solubility of Pyridinium-Based Tetrafluoroborates and Toluene
}

\author{
Jana Dreiseitlová,*, ${ }^{\dagger}$ Karel Řehák, ${ }^{\dagger}$ and Remko Vreekamp \\ Department of Physical Chemistry, Institute of Chemical Technology, Prague, 16628 Praha 6, Czech Republic, and Laboratorio \\ de Termodinámica y Fisicoquímica de Fluidos, Parque Científico-Tecnológico, Campus Universitario de Tafira, Universidad de \\ Las Palmas de Gran Canaria, 35071 Las Palmas de Gran Canaria, Canary Islands, Spain
}

\begin{abstract}
Mutual solubilities of pyridinium-based tetrafluoroborates (namely, 1-butylpyridinium tetrafluoroborate, 1-butyl-2-methylpyridinium tetrafluoroborate, 1-butyl-4-methylpyridinium tetrafluoroborate, and 1-hexylpyridinium tetrafluoroborate) and toluene were obtained at $(298.15,318.15$, and 338.15) K. The data were acquired by means of an experimental procedure utilizing gas chromatography and a gravimetric method. The results show that the liquid-liquid equilibrium in the studied systems is strongly asymmetrical. While the mole fraction solubility of the pyridinium-based ionic liquids in toluene ranges from $1.0^{\circ} 10^{-5}$ to $5.2 \cdot 10^{-5}$, the solubility of toluene in these ionic liquids varies from 0.318 to 0.579 in mole fraction. The experimental data were correlated with a semiempirical equation. Parameters of the nonrandom two-liquid (NRTL) equation were evaluated as well.
\end{abstract}

\section{Introduction}

Over the past decade, ionic liquids (ILs) have become one of the fastest growing "green" media for chemists and engineers because of their superb physicochemical properties. ILs are organic salts, with negligible vapor pressure, and have high thermal stability, with a wide temperature range for the liquid phase, and properties adapted by changing cations and/or anions. The applications of these remarkable salts in reactions and extraction processes have been extensively investigated and reviewed. Interest in the use of ILs to replace volatile solvents in industrial processes has increased greatly in recent years. ${ }^{1,2}$ To be able to competently substitute commonly used solvents by ILs, a good performance of estimation methods for activity coefficients will be required. The estimation methods based on interaction parameters of functional groups require experimental data on phase equilibria for mixtures of compounds having various functional groups. For these reasons, monofunctional benzene derivates are important, as they form the structure of many pharmaceuticals.

A bibliographic search of solubility data for all binary systems containing toluene and any IL was carried out. Data were found for the following ILs: 1-butyl-4-methylpyridinium tetrafluoroborate ([b4mpy] $\left.\left[\mathrm{BF}_{4}\right]\right),{ }^{3}$ 1-butyl-3-methylimidazolium tetrafluoroborate ([bmim] $\left.\left[\mathrm{BF}_{4}\right]\right),{ }^{4,5}$ 1-hexyloxymethyl-3-methylimidazolium tetrafluoroborate $\left(\left[\mathrm{C}_{6} \mathrm{H}_{13} \mathrm{OCH}_{2} \mathrm{mim}\right]\left[\mathrm{BF}_{4}\right]\right),{ }^{6}$ 1-ethyl3-methylimidazolium hexafluorophosphate $\left(\left[\mathrm{emim}^{2}\right]\left[\mathrm{PF}_{6}\right]\right){ }^{7}$ 1-butyl-3-methylimidazoliumhexafluorophosphate ([bmim] $\left.\left[\mathrm{PF}_{6}\right]\right),{ }^{4,7,8}$ 1,3-dimethylimidazolium methylsulfate $\left([\mathrm{mmim}]\left[\mathrm{CH}_{3} \mathrm{SO}_{4}\right]\right),{ }^{3,9}$ 1-butyl-3-methylimidazolium methylsulfate ([bmim] $\left.\left[\mathrm{CH}_{3} \mathrm{SO}_{4}\right]\right), 3,9$ 1-ethyl-3-methylimidazolium ethylsulfate $\left([\mathrm{emim}]\left[\mathrm{C}_{2} \mathrm{H}_{5} \mathrm{SO}_{4}\right]\right),{ }^{3,10}$ 1-ethyl-3-methylimidazolium bis(trifluoromethylsulfonyl)imide ([emim] $\left.\left[\mathrm{Tf}_{2} \mathrm{~N}\right]\right),{ }^{11} 1$-hexyloxymethyl-3-methyl-imidazolium bis(trifluoromethylsulfonyl)imide $\left(\left[\mathrm{C}_{6} \mathrm{H}_{13} \mathrm{OCH}_{2} \mathrm{mim}\right]\left[\mathrm{Tf}{ }_{2} \mathrm{~N}\right]\right){ }^{6}$ eth-

\footnotetext{
* Corresponding author. Address: Department of Physical Chemistry, Institute of Chemical Technology, Prague, Technická 5, 16628 Praha 6, Czech Republic. Tel.: +420 220444 039. E-mail: jana.dreiseitlova@ vscht.cz. † Institute of Chemical Technology. E-mail: karel.rehak@vscht.cz (K.R.). † Universidad de Las Palmas de Gran Canaria. E-mail: rvreekamp@ramonycajal.ulpgc.es (R.V.).
}

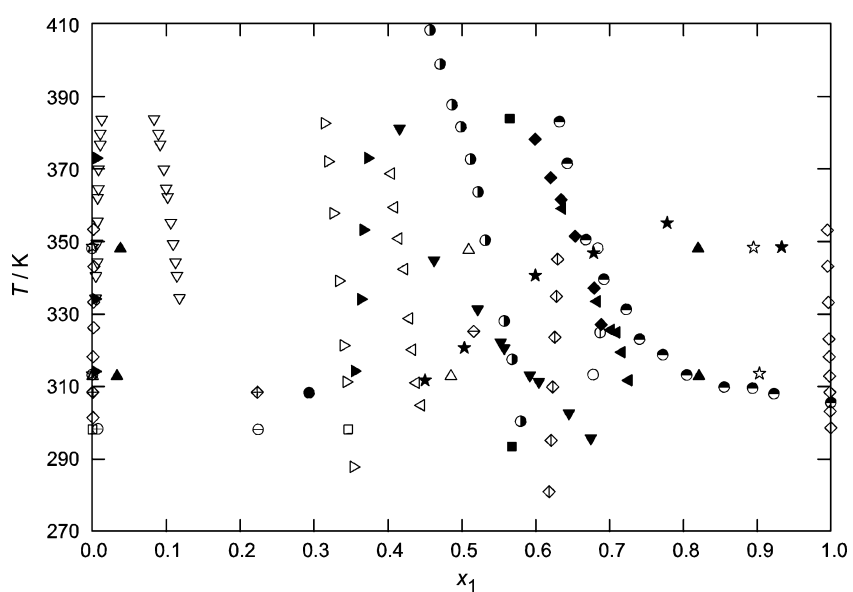

Figure 1. Literature solubility data in systems containing toluene and an IL: $\triangle,[\mathrm{b} 4 \mathrm{mpy}]\left[\mathrm{BF}_{4}\right] ;^{3} \oplus, \diamond,[\mathrm{bmim}]\left[\mathrm{BF}_{4}\right]^{4,5}$ open right-pointing triangle, $\left[\mathrm{C}_{6} \mathrm{H}_{13} \mathrm{OCH}_{2} \mathrm{mim}\right]\left[\mathrm{BF}_{4}\right] ;^{6} \diamond,[\mathrm{emim}]\left[\mathrm{PF}_{6}\right] ;^{7} \diamond, \mathbf{a}, \ominus,[\mathrm{bmim}]\left[\mathrm{PF}_{6}\right]^{4,7,8}$ 光, $\ominus,[\mathrm{mmim}]\left[\mathrm{CH}_{3} \mathrm{SO}_{4}\right]^{3,9} \mathrm{O}, \boldsymbol{\nabla},[\mathrm{bmim}]\left[\mathrm{CH}_{3} \mathrm{SO}_{4}\right]^{3,9} \boldsymbol{\Delta}$, solid left-pointing triangle, [emim] $\left[\mathrm{C}_{2} \mathrm{H}_{5} \mathrm{SO}_{4}\right]^{3,10}$ solid right-pointing triangle, [emim] $\left[\mathrm{Tf}_{2} \mathrm{~N}\right]$; $^{11}$ $\nabla,\left[\mathrm{C}_{6} \mathrm{H}_{13} \mathrm{OCH}_{2} \mathrm{mim}\right]\left[\mathrm{Tf}_{2} \mathrm{~N}\right] ;{ }^{6}$ O, $\mathrm{C}_{2} \mathrm{NTf}_{2} ;{ }^{12} \square,\left[\mathrm{C}_{2} \mathrm{mim}\right]\left[\mathrm{NTf}_{2}\right] ;^{13} \star$, $[\mathrm{BA}]\left[\mathrm{NO}_{3}\right],{ }^{14}$ diamond with vertical line, $[\mathrm{bmim}][\mathrm{SCN}] ;{ }^{15}$ open left-pointing triangle, $[\mathrm{b} 4 \mathrm{mpy}][\mathrm{TOS}] ;{ }^{16} \bigcirc,[\mathrm{emim}]\left[\mathrm{I}_{3}\right]{ }^{17}$ diamond with cross, [bmi$\mathrm{m}]\left[\mathrm{I}_{3}\right] .{ }^{17}$

yl(2-hydroxyethyl)dimethylammonium bis(trifluomethylsulfonyl)imide $\left(\mathrm{C}_{2} \mathrm{NTf}_{2}\right),{ }^{12}$ 1-ethyl-3-methylimidazoliumbis(trifluoromethylsulfonyl)amide $\left(\left[\mathrm{C}_{2}\right.\right.$ mim $\left.]\left[\mathrm{NTf}_{2}\right]\right),{ }^{13}$ (benzyl)dimethylalkyl ammonium nitrate $\left([\mathrm{BA}]\left[\mathrm{NO}_{3}\right]\right),{ }^{14}$ 1-butyl-3-methylimidazolium thiocyanate ([bmim] $[\mathrm{SCN}]),{ }^{15}$ 1-butyl-4-methylpyridinium tosylate ( $p$-toluenesulfonate) ([b4mpy][TOS]), ${ }^{16} 1$-ethyl-3-methylimidazolium triiodide $\left([\mathrm{emim}]\left[\mathrm{I}_{3}\right]\right),{ }^{17}$ and 1-butyl-3-methylimidazolium triiodide $\left([\mathrm{bmim}]\left[\mathrm{I}_{3}\right]\right) .{ }^{17}$ Figure 1 shows a great variability in miscibility of the mentioned ILs with toluene. The bibliographic search revealed discrepancies in all published data for the same particular systems. It also can be seen that this type of binary system has not been studied systematically. Solubility data are often available only for the IL-rich phase. In some cases, zero values for solubility of ILs in toluene are given in publications. No systematic measurement for the 
Table 1. Manufacturer, Density $\rho$ at $T=298.15 \mathrm{~K}$, Purity $\omega$, and Water Mass Fraction $\omega\left(\mathrm{H}_{2} \mathrm{O}\right)$ of the Compounds Used

\begin{tabular}{|c|c|c|c|c|c|}
\hline compound & manufacturer & \multicolumn{2}{|c|}{$\rho(298.15 \mathrm{~K}) / \mathrm{g} \cdot \mathrm{cm}^{-3}$} & $\frac{\text { GC purity }^{a}}{100 \omega}$ & $100 \omega\left(\mathrm{H}_{2} \mathrm{O}\right)$ \\
\hline$[\mathrm{bpy}]\left[\mathrm{BF}_{4}\right]$ & Iolitec & 1.2140 & $1.2144^{18}$ & 99 & 0.020 \\
\hline$[\mathrm{b} 4 \mathrm{mpy}]\left[\mathrm{BF}_{4}\right]$ & Iolitec & 1.1831 & $1.1827^{20}$ & 99 & 0.025 \\
\hline$[\mathrm{hpy}]\left[\mathrm{BF}_{4}\right]$ & Iolitec & 1.1548 & $1.154^{21}$ & 99 & 0.035 \\
\hline toluene & Fluka & 0.86227 & $0.86219^{22}$ & 99.7 & 0.020 \\
\hline benzene & Aldrich & 0.87340 & $0.87360^{22}$ & 99.8 & 0.024 \\
\hline
\end{tabular}

${ }^{a}$ Declared by the manufacturer.

systems of pyridinium-based tetrafluoroborates + toluene was found in literature. For these reasons, this work deals with the experimental determination of the mutual solubilities of those ILs and toluene and presents new solubility data for 1-butylpyridinium tetrafluoroborate $\left([\mathrm{bpy}]\left[\mathrm{BF}_{4}\right]\right), 1$-butyl-2-methylpyridinium tetrafluoroborate ([b2mpy] $\left[\mathrm{BF}_{4}\right]$ ), 1-butyl-4-methylpyridinium tetrafluoroborate $\left([\mathrm{b} 4 \mathrm{mpy}]\left[\mathrm{BF}_{4}\right]\right)$, and 1-hexylpyridinium tetrafluoroborate $\left([\mathrm{hpy}]\left[\mathrm{BF}_{4}\right]\right)$ at $(298.15,318.15$, and 338.15) $\mathrm{K}$.

\section{Experimental Section}

Chemicals and Apparatus. Specifications of chemicals used in this work are given in Table 1. Water content was determined by the Karl Fischer titration using an automatic buret and titration controller from Mettler (DL-18) or Schott. Densities were measured by an Anton Paar DMA 58 vibrating-tube digital densimeter. The working temperature of the densimeter was controlled within $\pm 0.01 \mathrm{~K}$. The instrument was calibrated with several liquids. ${ }^{23}$ For samples with low viscosity, the uncertainty of density measurements was $\pm 2 \cdot 10^{-5} \mathrm{~g} \cdot \mathrm{cm}^{-3}$. Since no viscosity correction was applied, the uncertainty of the IL density measurement was estimated to be $\pm 3 \cdot 10^{-4} \mathrm{~g} \cdot \mathrm{cm}^{-3}$. Because of the highly hygroscopic nature of ILs, all main manipulations with them were performed in a drybox.

Procedures. Mutual solubility data for above-mentioned ILs and toluene were acquired using a direct analytical method, which consisted of a direct analysis of the conjugated phases. Heterogeneous mixtures for sampling were prepared in a thermostatted equilibrium cell. The liquid mixture was thermostatted to the required temperature $( \pm 0.1 \mathrm{~K})$, agitated for at least $5 \mathrm{~h}$, and then left to stand for at least $3 \mathrm{~h}$ to allow the two phases to separate. Samples taken from the both liquid phases were then analyzed. The analysis of the IL-rich phase was carried out by means of gas chromatography. Determination of the IL content in the toluene-rich phase was performed gravimetrically using an analytical balance and a rotary evaporator.

Gas Chromatography. An Agilent 6890N gas chromatograph with a flame ionization detector (FID) was employed to carry out the GC analyses. To determine the content of toluene in the IL-rich equilibrium phase, an HP-5 cross-linked (5 \% phenylmethylpolysiloxane) capillary column $(30 \mathrm{~m} \times 0.32 \mathrm{~mm} \times 0.25$ $\mu \mathrm{m}$ ) was used with the temperature program of $70{ }^{\circ} \mathrm{C}$ for 2 min, (70 to 180$){ }^{\circ} \mathrm{C}$ at $25^{\circ} \mathrm{C} \cdot \mathrm{min}^{-1}, 180{ }^{\circ} \mathrm{C}$ for $1 \mathrm{~min}$, and split (50:1) mode injection. To prevent the IL from getting into the column, a short guard column was used before the column. The chromatograph was calibrated with methanol solutions of known compositions of toluene and benzene, which was utilized as the internal standard. The obtained data were then used for the evaluation of calibration equations. The samples taken from the cell were diluted with methanol to adjust their compositions approximately to those of calibration mixtures. Three samples were prepared from each liquid phase, and each sample was analyzed five times. From the GC analyses of the calibration
Table 2. Conjugated-Phase Mole and Mass Fractions for the Systems $[\mathrm{bpy}]\left[\mathrm{BF}_{4}\right],[\mathrm{b} 2 \mathrm{mpy}]\left[\mathrm{BF}_{4}\right],[\mathrm{b} 4 \mathrm{mpy}]\left[\mathrm{BF}_{4}\right]$, $[\mathrm{hpy}]\left[\mathrm{BF}_{4}\right]$, and Toluene

\begin{tabular}{|c|c|c|c|c|}
\hline \multirow{2}{*}{$\frac{T}{\mathrm{~K}}$} & \multicolumn{2}{|c|}{ toluene-rich phase } & \multicolumn{2}{|c|}{ IL-rich phase } \\
\hline & $x_{1}^{\prime}$ & $w_{1}^{\prime}$ & $x_{1}^{\prime \prime}$ & $w_{1}^{\prime \prime}$ \\
\hline \multicolumn{5}{|c|}{$[\mathrm{bpy}]\left[\mathrm{BF}_{4}\right](1)+$ Toluene $(2)$} \\
\hline 298.15 & $1.0 \cdot 10^{-5}$ & $2.5 \cdot 10^{-5}$ & 0.680 & 0.837 \\
\hline 318.15 & $1.3 \cdot 10^{-5}$ & $3.2 \cdot 10^{-5}$ & 0.682 & 0.839 \\
\hline 338.15 & $1.5 \cdot 10^{-5}$ & $3.5 \cdot 10^{-5}$ & 0.676 & 0.834 \\
\hline \multicolumn{5}{|c|}{$[\mathrm{b} 2 \mathrm{mpy}]\left[\mathrm{BF}_{4}\right](1)+$ Toluene $(2)$} \\
\hline 298.15 & $1.6 \cdot 10^{-5}$ & $4.0 \cdot 10^{-5}$ & 0.628 & 0.813 \\
\hline 318.15 & $2.8 \cdot 10^{-5}$ & $7.1 \cdot 10^{-5}$ & 0.643 & 0.823 \\
\hline 338.15 & $3.5 \cdot 10^{-5}$ & $8.9 \cdot 10^{-5}$ & 0.661 & 0.834 \\
\hline \multicolumn{5}{|c|}{$[\mathrm{b} 4 \mathrm{mpy}]\left[\mathrm{BF}_{4}\right](1)+$ Toluene $(2)$} \\
\hline 298.15 & $4.1 \cdot 10^{-5}$ & $1.0 \cdot 10^{-4}$ & 0.525 & 0.740 \\
\hline 318.15 & $4.7 \cdot 10^{-5}$ & $1.2 \cdot 10^{-4}$ & 0.543 & 0.754 \\
\hline 338.15 & $5.2 \cdot 10^{-5}$ & $1.3 \cdot 10^{-4}$ & 0.554 & 0.762 \\
\hline \multicolumn{5}{|c|}{$[\mathrm{hpy}]\left[\mathrm{BF}_{4}\right](1)+$ Toluene $(2)$} \\
\hline 298.15 & $2.8 \cdot 10^{-5}$ & $7.6 \cdot 10^{-5}$ & 0.421 & 0.665 \\
\hline 318.15 & $2.8 \cdot 10^{-5}$ & $7.6 \cdot 10^{-5}$ & 0.441 & 0.683 \\
\hline 338.15 & $1.3 \cdot 10^{-5}$ & $8.5 \cdot 10^{-5}$ & 0.453 & 0.693 \\
\hline
\end{tabular}

mixtures and from the repeatability of the measurements, the mole fraction uncertainty of the results was estimated to be \pm 0.015 .

Gravimetric Method. The nonvolatility of ILs was exploited for the determination of their solubilities in toluene. A known amount of the sample taken from the toluene-rich phase was loaded into a small $(25 \mathrm{~mL})$ round-bottom flask which was then connected to a rotary evaporator. Toluene was evaporated from the sample at $330 \mathrm{~K}$ under vacuum until it reached a stable weight. The flask with the nonvolatile residue was disconnected from the evaporator and weighed. To avoid possible absorption of air humidity, the vacuum apparatus was filled with dry nitrogen before disconnecting the flask. On the basis of simple mass balance, the composition of an IL in the toluene-rich phase was calculated. Measurements at each temperature were repeated three times. The mole fraction uncertainty of the results was estimated to be $\pm 0.5 \cdot 10^{-5}$.

\section{Results and Discussion}

Mutual solubility data for the ILs $[\mathrm{bpy}]\left[\mathrm{BF}_{4}\right],[\mathrm{b} 2 \mathrm{mpy}]\left[\mathrm{BF}_{4}\right]$, $[\mathrm{b} 4 \mathrm{mpy}]\left[\mathrm{BF}_{4}\right]$, and $[\mathrm{hpy}]\left[\mathrm{BF}_{4}\right]$ with toluene were obtained at $(298.15,318.15$, and 338.15) K. The experimental data in both mole and mass fractions are listed in Table 2. The corresponding liquid-liquid equilibrium diagram is given in Figure 2. Solubilities of the studied ILs $\left(x_{1}^{\prime}\right)$ in toluene are very low. They were found to be slightly increasing with temperature. Contrary to that, the solubility of toluene in the mentioned ILs (i.e., the value $\left.x_{2}^{\prime \prime}=1-x_{1}{ }^{\prime \prime}\right)$ is high and decreasing with temperature. This trend was confirmed by the experiment: a heterogeneous mixture of $[\mathrm{b} 4 \mathrm{mpy}]\left[\mathrm{BF}_{4}\right]+$ toluene was prepared in a thermostatted specimen tube, brought to equilibrium at $(298.15,318.15$, and 338.15$) \mathrm{K}$, and then quickly heated up or cooled down. 


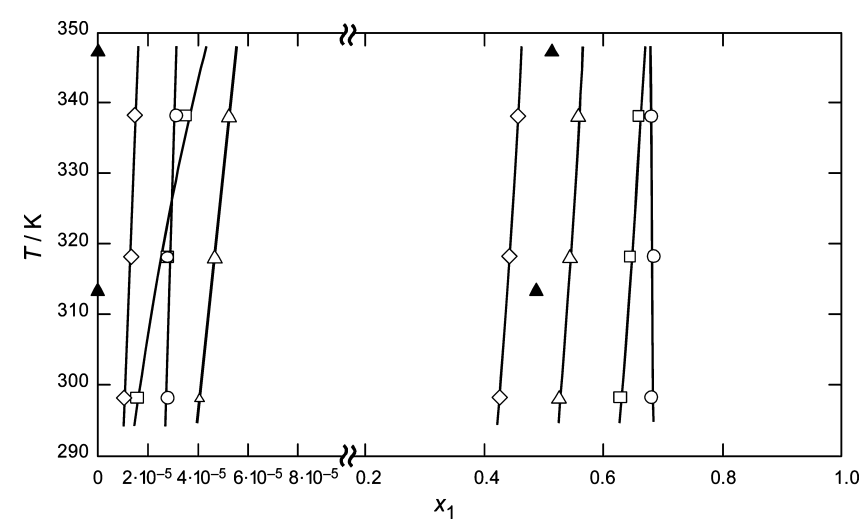

Figure 2. Experimental data on liquid-liquid equilibrium in systems: $O$, $[$ bpy $]\left[\mathrm{BF}_{4}\right](1)+$ toluene (2); $\square,[\mathrm{b} 2 \mathrm{mpy}]\left[\mathrm{BF}_{4}\right](1)+$ toluene $(2) ; \Delta$, $[\mathrm{b} 4 \mathrm{mpy}]\left[\mathrm{BF}_{4}\right](1)+$ toluene $(2) ; \diamond,[\mathrm{hpy}]\left[\mathrm{BF}_{4}\right](1)+$ toluene $(2) ; \mathbf{\Delta}$, literature data $[\mathrm{b} 4 \mathrm{mpy}]\left[\mathrm{BF}_{4}\right](1)+$ toluene $(2) .^{3}$ Solid lines represent data obtained by means of eqs 1 and 2 .

During cooling down no turbidity ever appeared, while on heating up turbidity always appeared in the IL-rich phase.

The mole fraction solubility of the pyridinium-based ILs in toluene ranges from $1.0 \cdot 10^{-5}$ to $5.2 \cdot 10^{-5}$; the solubility of toluene in these ILs varies from 0.318 to 0.579 in mole fraction. The obtained results on the solubility of toluene in $[\mathrm{b} 4 \mathrm{mpy}]\left[\mathrm{BF}_{4}\right]$ can be compared with data published by Meindersma et al. ${ }^{3}$ The comparison confirmed the temperature trend of the solubility. Both sets of experimental data, however, differ by about 0.05 in mole fraction. Discrepancies of experimental data in similar systems (listed in the Introduction) were found to be quite frequent. They are probably caused by the presence of different amounts of water in each particular measured system.

The correlations of the temperature dependence of the mole fraction solubilities of ILs in toluene $\left(x_{1}{ }^{\prime}\right)$ and toluene in ILs $\left(x_{2}{ }^{\prime \prime}=1-x_{1}{ }^{\prime \prime}\right)$ were performed by means of the equations

$$
\begin{aligned}
& \ln x_{1}^{\prime}=A^{\prime}+\frac{B^{\prime}}{T / \mathrm{K}} \\
& \ln x_{2}^{\prime \prime}=A^{\prime \prime}+\frac{B^{\prime \prime}}{T / \mathrm{K}}
\end{aligned}
$$

The calculated parameters $A^{\prime}, B^{\prime}, A^{\prime \prime}$, and $B^{\prime \prime}$ are summarized in Table 3.

Besides eqs 1 and 2, the nonrandom two-liquid (NRTL) model was used for the thermodynamic descriptions of the studied systems. The NRTL parameters were employed in the form

$$
\begin{aligned}
\tau_{12} & =\frac{a_{12}}{T} \\
\tau_{21} & =\frac{a_{21}}{T}
\end{aligned}
$$

Table 3 summarizes the values of $a_{12}$ and $a_{21}$ for nonrandomness parameter $\alpha=0.2$.

\section{Conclusion}

Liquid-liquid equilibrium data were measured for pyridinium-based tetrafluoroborates (namely, 1-butylpyridinium tetrafluoroborate $[\mathrm{bpy}]\left[\mathrm{BF}_{4}\right], 1$-butyl-2-methylpyridinium tetrafluoroborate $[\mathrm{b} 2 \mathrm{mpy}]\left[\mathrm{BF}_{4}\right], 1$-butyl-4-methylpyridinium tetrafluoroborate $[\mathrm{b} 4 \mathrm{mpy}]\left[\mathrm{BF}_{4}\right]$, and 1-hexylpyridinium tetrafluoroborate $[\mathrm{hpy}]\left[\mathrm{BF}_{4}\right]$ ) and toluene. The results show that the liquid-liquid equilibrium in the studied systems is strongly asymmetrical. It was found that the structure of the cation only
Table 3. Calculated Parameters for the Equations 1 and 2 and for the NRTL Equation with $\alpha=0.2$

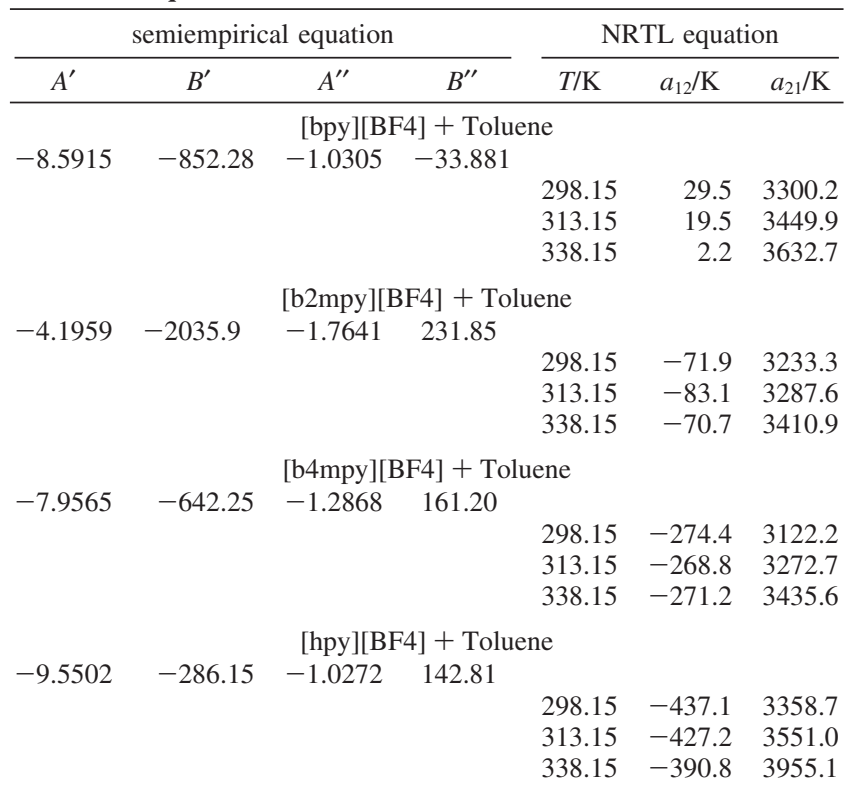

has a little effect on the solubility of the mentioned ILs in toluene. The solubility is very low in all cases. On the other hand, the solubility of toluene in the ILs is notably increasing with the increasing number of carbon atoms in the alkyl chain attached with the pyridinium ring. In molecules where the number of carbon atoms is the same the solubility is higher for the para position of the methyl group than for its ortho position.

\section{Literature Cited}

(1) Hoefer, R.; Bigorra, J. Green chemistry-A sustainable solution for industrial specialties applications. Green Chem. 2007, 93, 203-212.

(2) Zhao, H. Innovative applications of ionic liquids as "green" engineering liquids. Chem. Eng. Commun. 2006, 193, 1660-1677.

(3) Meindersma, G. W.; Podt, A. J. G.; de Haan, A. B. Ternary liquidliquid equilibria for mixtures of toluene $+n$-heptane + an ionic liquid. Fluid Phase Equilib. 2006, 247, 158-168.

(4) Huo, Y.; Xia, S.; Ma, P. Solubility of Alcohols and Aromatic Compounds in Imidazolium-Based Ionic Liquids. J. Chem. Eng. Data 2008, 53, 2535-2539.

(5) Shang, H.-T.; Wu, J.-S.; Zhou, Q.; Wang, L.-S. Solubilities of Benzene, Toluene, and Xylene Isomers in 1-Butyl-3-methylimidazolium Tetrafluoroborate. J. Chem. Eng. Data 2006, 51, 1286-1288.

(6) Domanska, U.; Marciniak, A. Liquid phase behaviour of 1-hexyloxymethyl-3-methyl-imidazolium-based ionic liquids with hydrocarbons. The influence of anion. J. Chem. Thermodyn. 2005, 37, 577-585.

(7) Domanska, U.; Marciniak, A. Solubility of 1-Alkyl-3-methylimidazolium Hexafluorophosphate in Hydrocarbons. J. Chem. Eng. Data 2003, 48, 451-456.

(8) Maduro, R. M.; Aznar, M. Liquid-liquid equilibrium of ternary systems 1-butyl-3-methylimidazolium hexafluorophosphate + aromatic + aliphatic. Fluid Phase Equilib. 2008, 265, 129-138.

(9) Domanska, U.; Pobudkowska, A.; Eckert, F. Liquid-liquid equilibria in the binary systems (1,3-dimethylimidazolium, or 1-butyl-3-methylimidazolium methylsulfate + hydrocarbons). Green Chem. 2006, 8, 268-276.

(10) Domanska, U.; Laskowska, M.; Marciniak, A. Phase Equilibria of (1Ethyl-3-methylimidazolium Ethylsulfate + Hydrocarbon, + Ketone, and + Ether) Binary Systems. J. Chem. Eng. Data 2008, 53, 498502.

(11) Shiflett, M. B.; Niehaus, A. M. S. Liquid-Liquid Equilibria in Binary Mixtures Containing Substituted Benzenes with Ionic Liquid 1-Ethyl3-methylimidazolium Bis(trifluoromethylsulfonyl)imide. J. Chem. Eng. Data 2010, 55, 346-353.

(12) Domanska, U.; Marciniak, A.; Krolikowski, M. Phase Equilibria and Modeling of Ammonium Ionic Liquid, C2NTf2, Solutions. J. Phys. Chem. B 2008, 112, 1218-1225.

(13) Arce, A.; Earle, M. J.; Rodriguez, H.; Seddon, K. R.; Soto, A. 1-Ethyl3-methylimidazolium bis $\{$ (trifluoromethyl)sulfonyl $\}$ amide as solvent for the separation of aromatic and aliphatic hydrocarbons by liquid 
extraction - extension to C7- and C8-fractions. Green Chem. 2008, 10, 1294-1300.

(14) Domanska, U.; Bakala, I.; Pernak, J. Phase Equilibria of an Ammonium Ionic Liquid with Organic Solvents and Water. J. Chem. Eng. Data 2007, 52, 309-314.

(15) Domanska, U.; Laskowska, M.; Pobudkowska, A. Phase Equilibria Study of the Binary Systems (1-Butyl-3-methylimidazolium Thiocyanate Ionic Liquid + Organic Solvent or Water). J. Phys. Chem. B 2009, 113, 6397-6404.

(16) Domanska, U.; Krolikowski, M.; Pobudkowska, A.; Letcher, T. M Phase Equilibria Study of the Binary Systems (N-Butyl-4-methylpyridinium Tosylate Ionic Liquid + Organic Solvent, or Water). J. Chem. Eng. Data 2009, 54, 1435-1441.

(17) Selvan, M. S.; McKinley, M. D.; Dubois, R. H.; Atwood, J. L. LiquidLiquid Equilibria for Toluene + Heptane + 1-Ethyl-3-methylimidazolium Triiodide and Toluene + Heptane + 1-Butyl-3-methylimidazolium Triiodide. J. Chem. Eng. Data 2000, 45, 841-845.

(18) Gu, Z.; Brennecke, J. F. Volume Expansivities and Isothermal Compressibilities of Imidazolium and Pyridinium-Based Ionic Liquids. J. Chem. Eng. Data 2002, 47, 339-345.

(19) Bandres, I.; Pera, G.; Martin, S.; Castro, M.; Lafuente, C. Thermophysical Study of 1-Butyl-2-Methylpyridinium Tetrafluoroborate Ionic Liquid. J. Phys. Chem. B 2009, 113, 11936-11942.
(20) Heintz, A.; Klasen, D.; Lehmann, J. K. Excess Molar Volumes and Viscosities of Binary Mixtures of Methanol and the Ionic Liquid 4-Methyl-N-butylpyridinium Tetrafluoroborate at 25,40 , and $50{ }^{\circ} \mathrm{C}$. J. Solution Chem. 2002, 31, 467-476.

(21) Kimura, Y.; Hamamoto, T.; Terazima, M. Raman Spectroscopic Study on the Solvation of N,N-Dimethyl-p-nitroaniline in Room-Temperature Ionic Liquids. J. Phys. Chem. A 2007, 111, 7081-7089.

(22) Riddick, J. A.; Bunger, W. B.; Sakano, T. K. Organic Solvents. Physical Properties and Methods of Purification, 4th ed.; John Wiley \& Sons: New York, 1986.

(23) Ortega, J.; Espiau, F.; Toledo, F. J. Thermodynamic properties of (an ester + an alkane). XVI. Experimental $\mathrm{HmE}$ and VmE values and a new correlation method for (an alkyl ethanoate + an n-alkane) at 318.15 K. J. Chem. Thermodyn. 2004, 36, 193-209.

Received for review December 18, 2009. Accepted February 24, 2010. This work was supported from the Ministry of Education, Youth and Sports of the Czech Republic (Grant No. MSM 6046137307). The author J.D. acknowledges the scholarship provided by The National Agency for European Educational Programes (NAEP) within the Erasmus program.

JE901065E 